\title{
Financial Challenges for School Principals during the Covid-19 Pandemic
}

\author{
Alina Cristina CĂLDĂRARU, Gabriella SZEKERES and Mihai PĂUNICĂ \\ Bucharest University of Economic Studies, Bucharest, Romania
}

Correspondence should be addressed to: Alina Cristina CĂLDĂRARU; acaldararu@gmail.com

Received date:4 Mai 2021; Accepted date:26 August 2021; Published date: 25 January 2022

Academic Editor: Nicoleta Sîrghi

Copyright (C) 2022. Alina Cristina CĂLDĂRARU, Gabriella SZEKERES and Mihai PĂUNICĂ. Distributed under Creative Commons Attribution 4.0 International CC-BY 4.0

\begin{abstract}
The impact of the Covid-19 pandemic was felt around all industries and sectors of the economy. Some studies identify education as part of the direct hit sectors by the pandemic. While online learning and other forms of virtual learning innovations were introduced, the absence of students from campuses had a significant financial impact on schools. This study was undertaken in the form of quantitative secondary research to determine from an accounting perspective the specific extent of the financial challenge that the pandemic posed on principals. Findings from the study have proved that the overall quantum of funding that the schools received reduced significantly. This was particularly the case for pre-university institutions that rely more on external funding from the government. The inadequate funding forced most principals to cut down on their budgets. In some schools, there was a shortage of logistics to effectively undertake the virtual learning program. Going into the future, recommendations have been made on the need to diversify the sources of funding of pre-university institutions.
\end{abstract}

Keywords: COVID-19, Education, Challenges, Pre-university

\section{Introduction}

The Covid-19 pandemic continues to affect millions of people worldwide. The pandemic affects people regardless of their gender, income, nationality, and educational level. The rate of infection and the lockdowns experienced during the beginning of the pandemic have impacted several individuals and institutions. The educational institution is no exception to the impact of the Covid-19 pandemic. In both developed and developing economies, the spread of the Covid-19 pandemic as well as various restrictions

Cite this Article as: Alina Cristina CĂLDĂRARU, Gabriella SZEKERES and Mihai PĂUNICĂ (2022)," Financial Challenges for School Principals during the Covid-19 Pandemic", Journal of e-Learning and Higher Education, Vol. 2022 (2022), Article ID 105890, DOI: 10.5171/2022.105890 
including lockdowns have exposed many of the inequalities and inadequacies within educational institutions (König, Jäger-Biela \& Glutsch, 2020). The lockdowns in response to Covid-19 have affected educational institutions as schools were closed to curb the spread of the virus. This situation affected how principles played their accounting roles in allocating resources given that accounting practices affect the overall management of pre-universities across the globe (Green \& Ferry, 2021). As many studies have focused on the impact of Covid-19 on educational institutions, this quantitative study will analyze studies that focus on the finances and financial challenges in pre-university institutions. As part of this purpose of the study, the following specific objectives will be pursued:

1. To determine the current state of pre-university funding as affected by the COVID-19 pandemic

2. To identify and keep budgeting challenges that principals of preuniversity institutions face as a result of the pandemic

3. To identify the challenge of dealing with inadequate funding without compromising on the quality of education

4. To identify the best practices for overcoming financing challenges during pandemics such as the Covid-19

The overall approach to the study is quantitative secondary research that makes use of real data on the financing of preuniversity institutions during the pandemic. The approach to accessing and extracting such data has been explained, as well as how statistical methods have been used to address the specific objectives.

\section{Literature Review}

As many studies have focused on the impact of Covid-19 on educational institutions, this literature will review studies that are focused on the finances and financial challenges in universities.

\section{Finances in Pre-universities}

Nemec et al (2020) discovered that the recent economic recession caused by the Covid-19 pandemic had affected several countries. The impact of the pandemic has had a serious effect on the various educational institutions with preuniversities hardly hit due to their reliance on the government for funding. Due to the impact of Covid-19 on the economy, the government, which is the main financier of schools, has been hit with challenges. In the wake of this, the government had responded in diverse ways including reducing funding, downsizing, restructuring, reducing revenue, and closure of schools at all levels (Altig et al, 2020). Schleicher (2021) mentioned two categories of funding for educational institutions. They are stateoriented funding in which the source of funding is by government and tuition fees. In the pre-universities for instance, funding is mostly by the government. The second category of funding is private-oriented in which funding of these institutions is largely by tuition fees and it serves as financial resources to other educational institutions financed privately and through tuition fees.

In the opinion of Zhou et al (2021), since most of the educational institutions are financed by the government, they were most affected by the economic recession caused by the Covid-19 pandemic. Following the claim made by Zhou et al (2021), it can be concluded that since pre-universities rely on government funding, the economic recession brought by the Covid-19 pandemic had had a great effect on funds allocation to these preuniversities. Based on the economic recession brought by the Covid-19 pandemic, both the government and preuniversities in the European Union developed plans to undertake financial reforms and another restructuring for financing the pre-universities after the Covid-19 pandemic had caused them to experience financial challenges (AlSamarrai, Gangwar \& Gala, 2020).

From the various write-ups, pre-universities are found to be financed by the government. Because of this, Nemec et al (2020) observed that since the pre-universities source of funding is from the state, they were faced 
with challenges of reduction of funding allocated to them. Following the economic recession because of the Covid-19 pandemic, they recommended that pre-universities must adjust to the reduction of fund allocation from the state. They suggested a diversification of funding from other sources as an alternative means to augment the reduced funding received from the state. Schleicher (2020) proposed a mixed structure of funds allocation to deal with any future challenges. According to them, the pre-universities should focus on mix funding structure that involves government-oriented funding and private-oriented funding. While the government becomes key in funds allocation to these institutions, funds from other sources will significantly relieve the institutions of the pressure of financial challenges. Schleicher (2020) believes that pre-universities can secure funding privately through high-quality education and sponsorship from other institutions to reduce their financial burden. They argued that when all other educational institutions financed by their respective government cut their overreliance on state funding and focus on other sources, the problem of reduced funding due to financial challenges on the part of the government will not affect their operations. Viner et al (2020) added that to be effective in financial reformation, there is the need for educational institutions to change internal processes and structures and reduce the cost of operation.

\section{Challenges in Support}

The number of resources needed in managing the affairs of educational institutions is a key determinant of the quality of education within the enclave of the various schools at all levels including preuniversities (Al-Samarrai, Gangwar \& Gala, 2020). In a general sense, the more funds provided or generated to support the preuniversities, the more likely it is that these institutions can ensure adequate infrastructure for the institutions and vice versa. The quality of education provided is also likely to be higher when the level of support is higher because more funds can be allocated to staff welfare, facilities, and services in the pre-universities. In the opinion of Nemec et al (2020), schools in Europe are impacted in different ways and times depending on the characteristics of their funding models. According to them, since the pre-universities depend largely on government funding, they are mostly affected in many ways in the short to long term when they are faced with challenges to that effect.

Viner et al (2020) opined that the mechanism of government funding plays a significant role in alleviating the financial burden of the pre-universities. In their view, any significant change in the level of support from public funding tends to produce short to long-term effects on the pre-universities. Brammer \& Clark (2020) discovered that the economic effect of the Covid-19 pandemic brought about significant financial challenges to pre-universities. In their opinion, the government was more focused on other sectors as part of measures to contain the spread of the virus and so their decision to reduce funds allocation to preuniversities. Montacute (2020) observed that as the various countries within the enclave of the European Union are impacted by the economic consequences of the Covid19 pandemic, the risk of public funding allocations to the educational institutions across Europe was reduced. According to them the reduced allocation of public funding was due to the increase in competition for public resources across the various sectors of the economy. They discovered that in the containment of the spread of the virus, the health sector was significant and so the budget to this sector was increased while it was reduced in the educational sector in general.

Brammer \& Clark (2020) observed that the issue of tuition fees is particularly significant in supporting educational institutions as this type of income generation represents an important percentage of the budget of the various educational institutions. According to them, tuition fees have remained significant in stabilizing the finances of educational institutions especially the fees of different groups of learners such as international students. In this regard, preuniversities will be relieved of any financial challenges if tuition fees are used to support funding from the government. They stated that the spread of Covid-19 amidst lockdowns in Europe affected income that 
the government will secure from international and other categories of students, and this led to a decrease in the level of support which brought a huge financial burden to these institutions.

\section{Challenges in Budgeting}

Budgeting is one of the basic roles in school accounting practices (Kenno et al., 2020). As the Covid-19 pandemic increased across various countries in Europe, many of the preuniversities in Europe were pushed to make a deep cut to widen budgets. In the analysis of instances of financial challenges in the educational institution, Zhou et al (2021) discovered that before the surge in the Covid-19 pandemic, government expenditure on pre-universities was high. According to them, the majority of the expenditure was allocated to recurrent expenses including supplements, wages, and purchase of goods and services while the rest was spent on development. These facts present evidence of how proactive governments within the enclave of the European Union were in their approach to pre-universities. In the opinion of Schleicher (2020), the situation looked different during the spike in the Covid-19 pandemic. Following their situational analysis, they discovered that apart from key recurrent expenditures such as wages and salaries, the budget for other developmental works was halted. They opined that the persistence of the economic recession caused by the Covid19 pandemic took a devastating financial toll on the budget of these pre-universities.

Adedoyin \& Soykan (2020) observed that the pressure to increase budget reached a critical mass throughout the various educational institutions in the months of the pandemic. Meanwhile, pre-universities were made to tighten their belt as they were informed to expect a steep reduction in funds appropriations as other areas of the economy also needed financial support. Montacute (2020) attributed the decrease in the budget for pre-universities to the increasing fund allocation needed for testing, tracing, and quarantining of affected people. Based on this, the pre-universities were engaged in cutbacks such as deferring developmental works and other less significant activities as part of measures to contain the budget allocation to the institutions.

\section{Challenges in Reducing Cost without Damaging Quality}

One of the main accounting responsibilities of principals is to ensure the cost-effective allocation of resources (Radjak \& Hiola, 2020). They do this by using accounting methodologies to reduce costs when presented with limited funding (Brusca et al., 2018). According to Hinrichs (2021), many educational institutions struggled with the fundamental challenges of having an income that does not cater to their expenses. Citing the situational analysis of Schleicher (2021) as an example, the pre-universities fund allocation was limited, and so various activities were stopped. Meanwhile, it is incumbent on all pre-universities to improve the quality of educational service they provide. Adedoyin \& Soykan (2020) identified a common cause of increased expenditure in pre-universities which is the quest to improve the quality of the services provided to learners in the pre-universities. However, Hinrichs (2021) argued that the problem with this is the ability to reduce cost without destroying the academic quality or the access and participation of learners. They advised that because the Covid-19 pandemic is devastating, pre-universities need to reduce direct cost which is always associated with the core of the institutions. According to them, the challenges of the pre-universities to reduce cost are direct and they have a significant influence on their finances.

Nemec et al (2020) argued that reducing cost will improve the finance of the preuniversities, however, the difficulty is the surge in the Covid-19 pandemic which makes it difficult for the pre-universities to do that. However, regardless of the increased rate of the Covid-19 pandemic and lockdowns, the pre-universities are expected to implement options that will facilitate learning. This could however not be effective without the use of innovative accounting practices (Ucieda \& Gonzalo-Angulo, 2019). Montacute (2020) observed that during the Covid-19 pandemic, spending for research, online tuition, and public services became a major expense for academic institutions. According to them, spending in these areas 
has increased at faster rates than before due to changes in technology which required consistent updating to enable these institutions to maintain the quality of education they provide to students.

\section{Methodology}

\section{Research method and design}

The study was conducted in the form of quantitative secondary research. The quantitative nature of the study meant the researcher used mathematical and numeric indices in presenting, analyzing, and interpreting data. Quantitative research generally serves the purpose of quantifying large volumes of data to describe phenomena, test existing theory (hypothesis) or understand the relationship between variables (Houghton, 2014). Based on the specific objectives of this study, almost all these three activities were to be performed at one point or the other. This was the reason the researcher opted for quantitative research. Secondary research on the other hand relies on existing data from other sources rather than those collected by the researcher at firsthand (Griffith, Shelton \& Kegler, 2017). There are several factors and conditions that make secondary research useful for a study. In this instance, secondary research was desirable due to the vastness of the research setting, which was the EU region. Collecting primary data from different countries during the time of pandemic would have been challenging and so it was important to rely on other existing sources of data.

\section{Population and sample}

The secondary research was conducted with principals of pre-university institutions within the EU region as population. What this meant was that while data were not going to be collected directly from the principals, the existing data had to be relative either directly or indirectly to the activities and roles of the principals. Within this population, a sample was set among seven major countries that are Spain, France, Romania, Switzerland, Germany, and Italy. The six countries were selected mainly due to the availability of data relating to school administration and management. This situation is in line with recommendations by Knox, S., \& Burkard (2019) who advocated for the use of research contexts that offers sufficient dataset when conducting secondary research of this nature. When there is a lack of data, the generalizability of findings for the secondary research becomes problematic (Jerolmack \& Khan, 2014).

\section{Search strategy}

In secondary research of this nature, the content of selected sources becomes the eventual results of the study (Griffith, Shelton \& Kegler, 2017). For this reason, it is important to put in a lot of effort in ensuring that selected sources are of high quality and contain sufficient data to address the research objectives. A search strategy was developed to ensure a systematic selection process for the best available sources. The idea behind the search was to collect six main articles or reports about the financing of preuniversity schools during the pandemic. Each of the six articles was to focus on one of the countries in the sample. The first step in the search strategy was to identify three databases where the sources will be selected.

Three electronic databases which are Educational Resources Information Center (ERIC), Google Scholar, and specific websites of popular schools were selected for this purpose. Next, keywords were set to be used in the search. Some of the keywords include pre-university funding, covid-19 and education funding, challenges of preuniversity funding, the impact of covid-19 on pre-universities, and education financing during the pandemic. With each of these keywords, the names of the countries were added to limit the scope of the search. Initial search produced sources that were more than what was needed. Therefore, an exclusion criterion was set to remove all those that were not published in the English language. Sources that were not complete were also excluded, as well as those that were reviews of existing studies. The final process involved skimming and scanning the shortlisted articles and documents to select the best six for further analysis.

The table below summarizes the articles and the countries they were selected to represent. 


\begin{tabular}{|l|l|}
\hline \multicolumn{1}{|c|}{ Article } & \multicolumn{1}{c|}{ Country represented } \\
\hline $\begin{array}{l}\text { Di Pietro, Biagi, Costa, Karpiński and Mazza } \\
(2020)\end{array}$ & Germany \\
\hline Giovannella, Marcello and Donatella (2020) & Italy \\
\hline Tomasik, Helbling and Moser (2020) & Switzerland \\
\hline Schleicher (2020) & Spain \\
\hline CEDEFOP (2020) & Romania \\
\hline OECD (2020) & France \\
\hline
\end{tabular}

\section{Data analysis plan}

The researcher employed content analysis in interpreting the data from secondary sources. This was done using close reading that led to thematic analysis of data from codes. That is, after the sources were collected, the researcher read through each of them slowly two times. During the reading, words and phrases that were emphasized, outstanding, repeated, or directly addressed any of the research objectives, were written down as codes. This included any numerical data relating to the financing of schools during the Covid-19 pandemic. The codes were subsequently categorized into themes to reflect the research objectives. In the next section, the results of the data analysis have been presented as results. Since the study is quantitative research, the results have been presented using statistical indices such as tables, percentages, charts, and correlational analysis.

\section{Findings}

This chapter presents the findings from the secondary data collection procedure that was conducted. The findings are presented in a thematic format to reflect the main objectives of the study.

\section{Challenges with funding levels}

Findings from all six countries included in the study showed a significant drop in the level of funding that educational institutions received during the pandemic in 2020 . The situation was attributed to the overall decline in economic growth throughout the EU region and across the globe. In table 1 below, the World Bank gives the GDP growth rate forecast for 2020 and compares that for the pre-COVID era.

Table 1: Growth rate for pre-COVID and COVID 2020

\begin{tabular}{|l|l|l|}
\hline & 2020 pre-COVID & \multicolumn{1}{|c|}{2020} \\
\hline Europe in general & $2.7 \%$ & $-5.7 \%$ \\
High income Europe & $2.1 \%$ & $-6.7 \%$ \\
Upper middle-income Europe & $4.1 \%$ & $-4.4 \%$ \\
Lower middle-income Europe & $4.0 \%$ & $-1.6 \%$ \\
Low-income Europe & $5.0 \%$ & $0.5 \%$ \\
\hline
\end{tabular}

Source: World Bank calculations from IMF (2019b and 2020b).

Note: Indicators are unweighted country averages.

From table 1, it would be noted that before the COVID pandemic, Europe as a whole was enjoying relating economic growth with a GDP rate of $2.7 \%$. Within the EU region itself, cities and countries that were lower in income levels were having higher growth rates due to increased government support and funding. However, with the COVID pandemic intensifying, the GDP growth rate dropped significantly for Europe as a whole 
and most income segments within the region. The direct link between the GDP and education financing was the reduction in funding to schools given the decline in economic growth that affected the education budget at the national level.

Table 2: Sources of funding for education in Europe

\begin{tabular}{|l|c|c|c|}
\hline & Government & Donors & Households \\
\hline Low income & 59 & 12 & 29 \\
\hline Low middle income & 73 & 3 & 24 \\
\hline Upper middle income & 75 & 0 & 25 \\
\hline High income & 82 & 2.8 & 18 \\
\hline
\end{tabular}

Source: World Bank calculations from IMF (2019b and 2020b).

Note: Indicators are unweighted country averages.

The data from the graph above show a very high dependence on the government for the funding of pre-universities across different income segments in Europe. While all of Europe has government as the major financier, the level of financing from the government increases with increasing income levels. Households also finance the schools to a significant level especially in private schools where parents pay for tuition. However, the economic impact of the pandemic that caused the decline in growth as depicted in table 1 also affected households through increased unemployment rates. Based on the two main factors above, which are declining economic growth and high dependence on government funding, the pandemic resulted in a drastically reduced level of funding received by principals during the pandemic. The situation is better depicted below.

Data gathered by the OECD and reported by Schleicher (2020) show that before the pandemic $11 \%$ of all public expenditure within the EU was devoted to education. This, however, dropped significantly to an average of $6 \%$ during the pandemic. The implication of this is that the pandemic resulted in lower levels of funding received by school principals.

\section{Challenges with budgeting}

Data were also collected to know how the pandemic affected the role of principals in preparing budgets to finance education during the pandemic. This theme was built on the first one that had confirmed reduced financing due to the pandemic. The researcher used this second theme to determine how the reduction in funding created challenges with budgeting for the principals. Through the content analysis, two major budget-related challenges were identified. These are content and scope challenges. The content challenges refer to the situation where the principals had to either include new items that were not originally planned for or had to remove useful items from the budget. The challenge of scope refers to the situation where the principals had to cut down on monetary allocation for existing expenditure. Through content analysis of the selected sources, the researcher classified the six countries into highly challenged, mildly challenged and lowly challenged for each of the two types of budgetary challenges. The table below represents the outcome of content analysis. 
Table 3: Extent of the budgetary challenge for principals

\begin{tabular}{|l|l|l|}
\hline \multicolumn{1}{|c|}{ Country } & Budget content challenge & Budget scope challenge \\
\hline Spain & Mild & High \\
France & High & High \\
Romania & High & High \\
Switzerland & Mild & High \\
Germany & High & High \\
Italy & High & High \\
\hline
\end{tabular}

Source: OECD

Table 2 shows a very significant impact of the reduced financing to schools on the budgeting that principals did. In all six countries, the content of sources was interpreted to show that principals experienced a high challenge with the scope of their budgets. This means the principals could not adequately allocate funds to capture the extent of expenditure as they used to do before the pandemic. In terms of content challenge with the budget, content interpreted from Spain and Switzerland show mild impacts as several principals in schools across those two countries already had vibrant virtual learning platforms that did not require new allocation for them. In the other four countries, however, the analysis of sources showed that a good number of schools particularly those in Germany had to make new provisions for virtual learning procurement and this caused challenges with the content of their budgets (Di Pietro, et al., 2020). In the country note for France, the OCED (2020) reports that the principals experienced a break in the supply chain and so even though they created new content for virtual learning budgeting, the materials could not arrive due to lockdown restrictions. In Romania, schools did not have the means to support "about 250000 learners $(9 \%$ from the total population of learners in State pre-university education) who did not have devices and Internet connection for online learning" (CEDEFOP, 2020).

\section{Reducing cost without damaging the quality}

Using the case of Switzerland, Tomasik (2020) quantified the impact of the pandemic on educational gains. This was done to determine if principals of primary and secondary schools faced the challenge of reducing the cost of education without damaging quality. The study involved a total $N=28,685$ students at the pre-university levels. The sample was made up of $50.3 \%$ boys and $49.7 \%$ girls. To measure the educational gains before and after the pandemic, the researchers divided the last eight weeks before the closure of schools and eight weeks after the closure of schools into intervals of 14 days. The weighted likelihood estimation (WLE) ability estimates of test items undertaken within the periods were graded and measured using probabilistic measurement theory involving the StockingLord equation model. Based on this, the results of the study showed that there was "a significant negative correlation between the intercept and the distance learning slope $(r=$ $-.27, p<.001$ )" (Tomasik, 2020, p. 18). This means that the students who "generally achieving higher made slower learning progress during the school closures and vice versa" (p. 18).

Meanwhile, data collected for OECD by Schleicher (2020) showed that the principals were faced with the challenge of maintaining the quality of educational output while reducing the funding available to them. From the findings, it can be said that the principals failed at maintaining the quality of education when the cost of running the schools was reduced due to the pandemic. This is because the novelty of distance learning and other forms of virtual education could not complement the gains made through inperson education. In Italy for example, the situation has been blamed on the fact that not all schools had the full complement of technology to run distance learning programs effectively (Giovannella, Marcello \& Donatella, 2020). Similarly, some 
households, particularly those in lowerincome areas, did not have adequate tools and technology at home to follow through with the distance learning programs that were introduced (Schleicher, 2020).

\section{Conclusion}

The Covid-19 pandemic had a serious negative effect on the financing of preuniversity institutions in the EU. The situation left several principals helpless as they were left with limited options on how to overcome the challenges. The financing challenges include, among others, the fact that they had to cut down on budgetary requirements, be indebted to workers and suppliers, and have the procurement supply chain broken. The direct impact of the financial challenge was the poor quality of education. While many saw the various forms of virtual learning as novel and innovative, the study has shown that it affected the overall quality of teaching and learning. The effect became significant as some principals were unable to get the full complement of logistics to run virtual education effectively. This means that the goal of reducing cost without damaging quality was not achieved for most principals. Going forward, several recommendations and best practices have been identified that can help minimize the impact of similar pandemics in the future. The main approach to addressing the challenge in the future is the need to promote auxiliary sources of funding and increase internally generated funding mechanisms of the schools. The current model relies extensively on external funding from the government, which when becomes compromised, limits the ability of schools to meet their budgetary requirements.

\section{References}

- Adedoyin, O. B., \& Soykan, E. (2020). Covid-19 pandemic and online learning: the challenges and opportunities. Interactive Learning Environments, 1-13.

- Al-Samarrai, S., Gangwar, M., \& Gala, P. (2020). The Impact of the COVID-19 pandemic on education financing. World Bank, Washington, DC. (C) World Bank.
- Schleicher, D., Baker, S., Barrero, J. M., Bloom, N., Bunn, P., Chen, S., ... \& Thwaites, G. (2020). Economic uncertainty before and during the COVID-19 pandemic. Journal of Public Economics, 191, 104274.

- Brammer, S., \& Clark, T. (2020). COVID19 and management education: Reflections on challenges, opportunities, and potential futures. British Journal of Management, 31(3), 453.

- $\quad$ Brusca, I., Caperchione, E., Cohen, S., \& Manes-Rossi, F. (2018). IPSAS, EPSAS, and other challenges in European public sector accounting and auditing. In The Palgrave handbook of public administration and management in Europe (pp. 165-185). Palgrave Macmillan, London.

- CEDEFOP (2020). Romania: Response to the COVID-19 outbreak. https://www.cedefop.europa.eu/en/ne ws-and-press/news/romaniaresponses-covid-19-outbreak

- Di Pietro, G., Biagi, F., Costa, P., Karpiński, Z., \& Mazza, J. (2020). The likely impact of COVID-19 on education: Reflections based on the existing literature and recent international datasets (Vol. 30275). Publications Office of the European Union.

- Giovannella, C., Marcello, P., \& Donatella, P. (2020). The effects of the Covid-19 pandemic on Italian learning ecosystems: The school teachers' Perspective at the steady-state. Research Gate. https://www.researchgate.net/publicat ion/344521289

- $\quad$ Green, S., \& Ferry, L. (2021). The impact of accounting disturbances on organizational micro-practices in the schools' sector in England. Accounting, Auditing \& Accountability Journal. 5(49), 43

- Griffith, D. M., Shelton, R. C., \& Kegler, M. (2017). Advancing the science of qualitative research to promote health equity. Health Education \& Behavior, 44, 673-676.

doi:10.1177/1090198117728549

- Hinrichs, P. L. (2021). COVID-19 and Education: A Survey of the Research. Economic Commentary, (2021-04). 
- Houghton, C., Murphy, K., Shaw, D., \& Casey, D. (2014). Qualitative case study data analysis: An example from practice. Nurse Researcher, 22(5), 8-12. doi:10.7748/nr.22.5.8.e1307

- Jerolmack, C., \& Khan, S. (2014). Talk is cheap: Ethnography and the attitudinal fallacy. Sociological Methods \& Research, 43 ,

178-209. doi:10.1177/0049124114523396

- Kenno, S., Lau, M., Sainty, B., \& Boles, B. (2020). Budgeting, strategic planning, and institutional diversity in higher education. Studies in Higher Education, 1-15.

- Knox, S., \& Burkard, A. W. (2019). Qualitative research interviews. Psychotherapy Research, 19, 566-575. doi:10.1080/10503300802702105

- König, J., Jäger-Biela, D. J., \& Glutsch, N. (2020). Adapting to online teaching during COVID-19 school closure: teacher education and teacher competence effects among early career teachers in Germany. European Journal of Teacher Education, 43(4), 608-622.

- Montacute, R. (2020). Social mobility and COVID-19: Implications of the COVID-19 crisis for educational inequality.

- Nemec, J., Drechsler, W., \& Hajnal, G. (2020). Public policy during COVID-19: Challenges for public administration and policy research in central and eastern Europe. NISPAcee Journal of Public Administration and Policy, 13(2), 11-22.

- OECD (2020). School education during covid 19 pandemic: were teachers and students ready. Country Note - France. https://www.oecd.org/education/Fran ce-coronavirus-education-countrynote.pdf

- Radjak, L. I., \& Hiola, Y. (2020). Accounting Guidelines Implementation: A Study on Economic Development of Islamic Boarding Schools. Journal of Asian Multicultural Research for Economy and Management Study, 1(2), 54-60.

- Schleicher, A. (2021). The impact of COVID-19 on education. Insights from Education at a Glance. OECD. https://www.oecd.org/education/theimpact-of-covid-19-on-educationinsights-education-at-a-glance-2020.pdf

- Tomasik, M. J., Helbling, L. A., \& Moser, U. (2020). Educational gains of in-person vs. distance learning in primary and secondary schools: A natural experiment during the COVID-19 pandemic school closures in Switzerland. International Journal of Psychology. Available at https://onlinelibrary.wiley.com/doi/ful l/10.1002/ijop.12728

- Ucieda, J. L., \& Gonzalo-Angulo, J. A. (2019). The Financial Crisis Impact on Institutions and Accounting Practices in Spain 1. In Institutions and Accounting Practices After the Financial Crisis (pp. 180-210). Routledge.

- Viner, R. M., Russell, S. J., Croker, H., Packer, J., Ward, J., Stansfield, C., ... \& Booy, R. (2020). School closure and management practices during coronavirus outbreaks including COVID19: a rapid systematic review. The Lancet Child \& Adolescent Health, 4(5), 397-404.

- Zhou, T., Molfino, T., \& Travers, J. (2021). The Cost of COVID: Understanding the Full Financial Impact of COVID-19 on Districts and Schools. Education Resource Strategies. 